\title{
The effect of protective atmosphere on decarburisation of the heat-treated surface of steel
}

\section{Vpliv zaščitne atmosfere na razogljičenje površine poboljšanega jekla}

\author{
Marica Prijanovič Tonkovič ${ }^{*}$, Miha Knez² \\ ${ }^{1}$ Višja strokovna šola Strojništvo, Novo mesto, Slovenia \\ ${ }^{2}$ Kovikor inženiring, trgovina in posredništvo, d. o. o., Dvor 21b, Šmartno pri Litiji, Slovenia \\ *marica.prijanovic-tonkovic@guest.arnes.si
}

\begin{abstract}
In heat-treating furnaces, many different types of protective atmospheres are used. This article researches the effect of protective atmospheres on the quality of the surface layer of bolts during the process of heating to reach the temperature of hardening. For this research, we produced specimens that were annealed in the furnace with two different types of protective atmosphere, i.e. in atmospheres of endothermic gas and nitrogen. After hardening and tempering, we measured the hardness of the specimens and investigated the microstructure. We measured the hardness profile from the surface to the inside of the product. We found that the hardness of the surface of the tested product was lower while using protective atmosphere of nitrogen due to the occurrence of ferrite. The depth of the decarburised layer in this atmosphere reached up to $70 \mathrm{~mm}$, where predominantly there was a microstructure of ferrite on the surface, and then, with depth, an increasingly mixed microstructure of ferrite and martensite was found. The depth of the decarburised layer for sample treated in endothermic gas was minimal (i.e. $10 \mathrm{~mm}$ ) on the surface.
\end{abstract}

Key words: heat treatment, protective atmosphere, decarburisation, endothermic gas, nitrogen, microstructure

\section{Izvleček}

$\mathrm{V}$ pečeh za toplotno obdelavo se uporablja različne zaščitne atmosfere. $\mathrm{V}$ članku smo preiskovali vpliv zaščitne atmosfere na kakovost površinske plasti vijaka med procesom segrevanja na temperaturo kaljenja.

Za preiskavo smo izdelali preizkušance, ki so se žarili v peči z dvema različnima zaščitnima atmosferama, tj. $\mathrm{v}$ atmosferi endoplina in dušika. Po kaljenju in popuščanju smo na preizkušancih izmerili trdoto in pregledali mikrostrukturo. Trdoto smo merili od površine izdelka v notranjost. Ugotovili smo, da je trdota na površini preizkušanega izdelka nižja v primeru uporabe zaščitne atmosfere dušika, zaradi pojava ferita. Globina razogljičene plasti v tej atmosferi sega do $70 \mathrm{~mm}$, kjer na površini prevladuje mikrostruktura ferita, nato pa se z globino povečuje mešana feritno-martenzitna mikrostruktura. Globina razogljičene plasti $v$ endoplinu je na površini minimalna in znaša $10 \mathrm{~mm}$.

Ključne besede: toplotna obdelava, zaščitna atmosfera, razogljičenje, endoplin, dušik, mikrostruktura 


\section{Introduction}

During heat treatment, the microstructure of metals and alloys gets changed due to different types of processes such as heating, holding at certain temperatures and cooling, and as a result, the physical and chemical characteristics also get altered. The atmosphere in furnaces plays a key role in this procedure. It can be oxidising, neutral or reducing, which depends on the heat treatment method [1-3]. During the heat treatment, especially during hardening, steel gets heated at the hardening temperature. During this time, there is a huge possibility of unwanted oxidation. This is why different gases that prevent the oxidation process are put in. These protective gases are methane, ethane, propane, argon, hydrogen, helium, or nitrogen, or alternatively, vacuum is used [4,5]. Using a protective atmosphere prevents oxidation and decarburisation of the surface or diffusion of some elements into the product surface $[6,7]$. Protective coatings also contribute to additional protection against oxidising and decarburisation of steel [8]. For high-quality heat treatment, electrical and gas furnaces with controlled protective atmospheres are used, especially in cases where we supply either a mixture of gases prepared beforehand or pure gases that are mixed in the furnaces. In this article, we studied the effect of the protective gas that is supplied into the furnace during the heat treatment on the microstructure and hardness of bolts made of steel coded 1.5510 by standard SIST EN 10027-2. The reason for conducting this research was the frequent occurrence of reduced hardness after heat treatment on the surface of the product.

Distance bolt is a product used for mounting in the automotive industry. If we want to produce pieces for the demanding automotive industry, it is necessary that the company obtain standard ISO/TS 16949 [9]. This standard determines the system of controlling the quality for development, design, manufacturing, mounting and service of automotive products. This way, the car manufacturers ensure control over the smallest piece that is mounted into the vehicle. This is also true for the bolt because factors such as where it is made, the type of material, its dimensions, hardness and plating depos- it are all important. The main goals of our research were as follows:

- Determining the depth of decarburisation in specimens tempered in an atmosphere of endothermic gas;

- determining the depth of decarburisation in specimens tempered in an atmosphere of nitrogen; and

- selecting a suitable gas for the production process.

\section{Materials and methods}

To determine the effect of different protective gases on the quality of the surface during the process of heating to the hardening temperature of steel coded 1.5510, we prepared two types of protective atmospheres. Thus, we heated the products in atmospheres of

- endothermic gas (i.e. mixture of air and pure propane in the ratio of $6.4: 0.8$ ) and

- nitrogen.

For specimens that were heated in the atmosphere of endothermic gas, the dew point temperature was $11.2^{\circ} \mathrm{C}$, and the content of carbon in the endothermic gas at a temperature of the generator equalling $900^{\circ} \mathrm{C}$ was $0.31 \%$. We carried out tests in electric resistance furnace type Safed T40 (Figure 1a). We transferred purified products, or rather bolts, in the heated-up furnace. The temperature in the furnace was $830^{\circ} \mathrm{C}$ in the first zone and in the other three zones, it was $870 \pm 5^{\circ} \mathrm{C}$. The duration of holding the temperature of hardening was 10 minutes. Then, we hardened the bolts in mineral oil Isomax $169[10,11]$ at a temperature of $55 \pm 5^{\circ} \mathrm{C}$. After the hardening process, heat treatment was carried out in a Safed 6/10 furnace at a temperature of $510^{\circ} \mathrm{C}$. The duration of annealing was 60 minutes. This was followed by preparation of the specimens for metallographic and hardness measurements. We measured the hardness based on Rockwell (Figure 1b) and later on Vickers. We examined the specimens using light and electronic microscopes. 

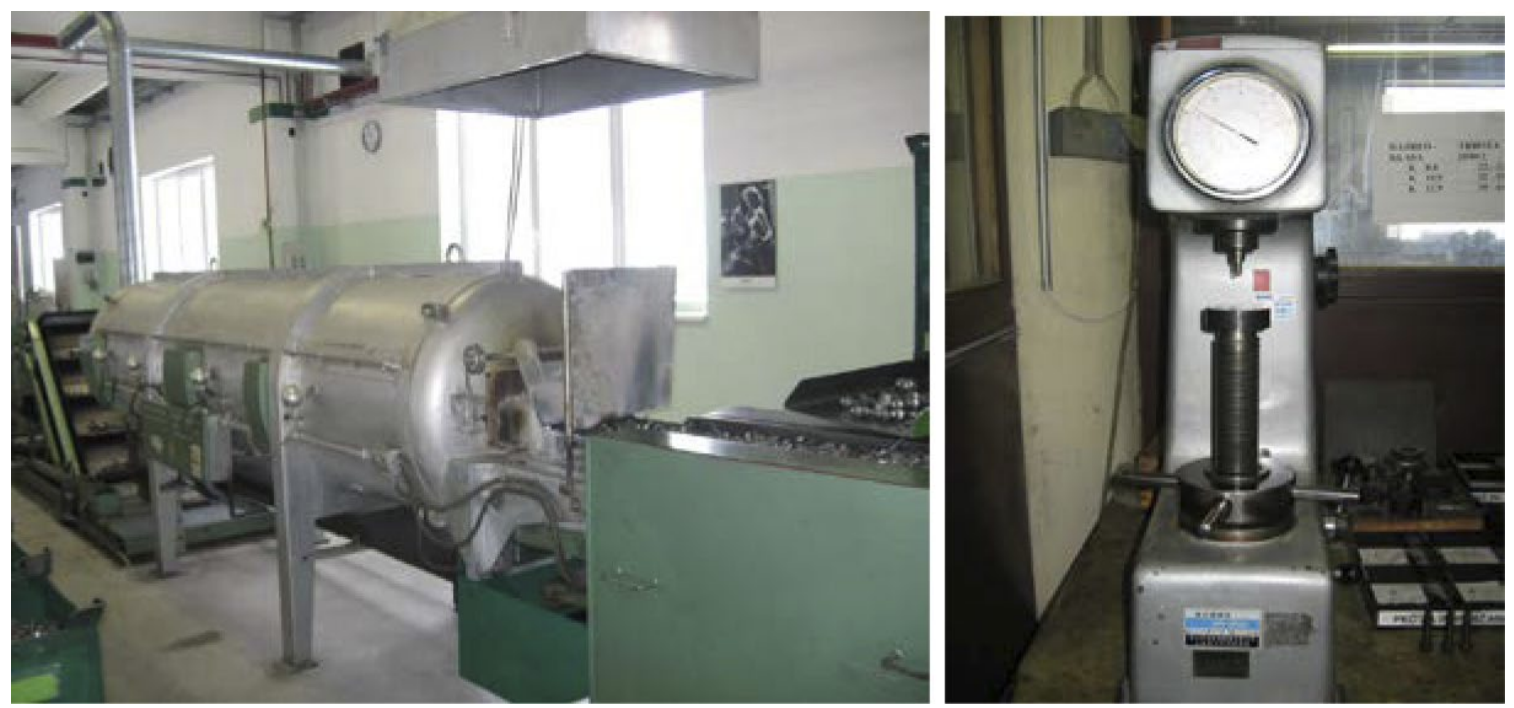

Figure 1: a) Hardening furnace Safed T40; b) hardness tester HR 150A.
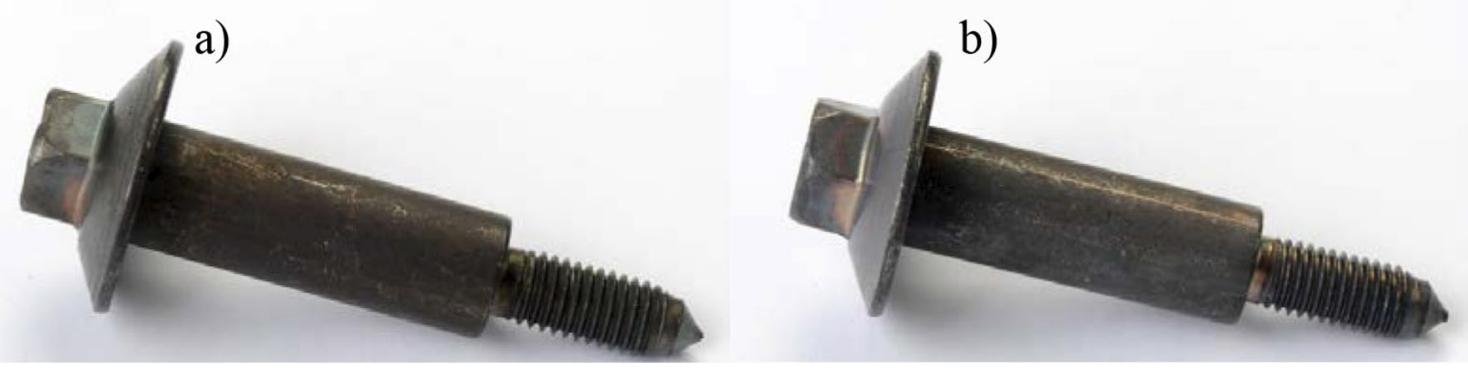

Figure 2: a) Bolt heated in nitrogen; b) bolt heated in endothermic gas.

Table 1: Results of hardness measurements from the edge of the specimen to the inside

\begin{tabular}{cccccccccc} 
Protective atmosphere & \multicolumn{10}{c}{ Hardness, HV } \\
\cline { 2 - 11 } & 1 & 2 & 3 & 4 & 5 & 6 & 7 & 8 & 9 \\
\hline Nitrogen & 216.4 & 357.1 & 388.5 & 393.3 & 390.9 & 388.5 & 382.0 & 389.6 & 413.4 \\
\hline Endothermic gas & 347.2 & 368.7 & 425.9 & 407.9 & 401.6 & 431.8 & 410.4 & - & - \\
\hline
\end{tabular}

\section{Results}

In this research, we studied the effect of the protective atmosphere present in the hardening furnace on the occurrence of surface decarburisation of the distance bolt. We carried out tests in two different protective atmospheres. Chemical analysis of steel yielded the following composition: $0.27 \% \mathrm{C} ; 0.8 \% \mathrm{Si} ; 0.9 \% \mathrm{Mn}$; $0.01 \% \mathrm{~S} ; 0.01 \% \mathrm{P}$ in $0.17 \% \mathrm{Cr}$. We heated the specimens in nitrogen atmosphere and in endothermic gas. To determine the decarburised surface, we used many methods with which we tested the quality of the surface.
Thus, we first measured the hardness based on the Rockwell method. The average hardness values of five bolts that were heated in the protective atmospheres of nitrogen and endothermic gas were $36.67 \mathrm{HRC}$ and 38.44 HRC, respectively. Figure $2 \mathrm{a}$ and $2 \mathrm{~b}$ shows the bolts before the metallographic tests.

We cut the bolts and prepared them for examination under the microscope. Then, measurement of hardness using the Vickers HV 0.3 method was carried out. The results of these measurements are shown in Table 1. Measurements were carried out using the testing machine manufactured by Zeiss. 

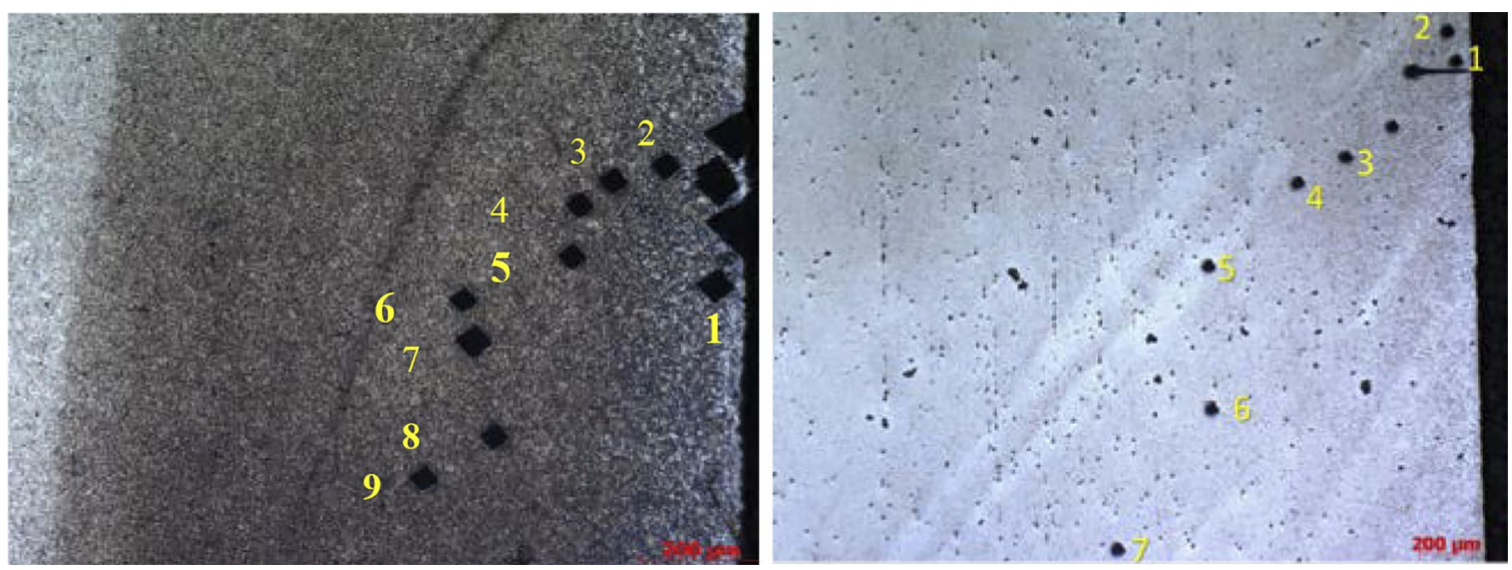

Figure 3: Hardness measurement points in the cross-sections of specimens heated in an atmosphere of a) nitrogen and b) endothermic gas.

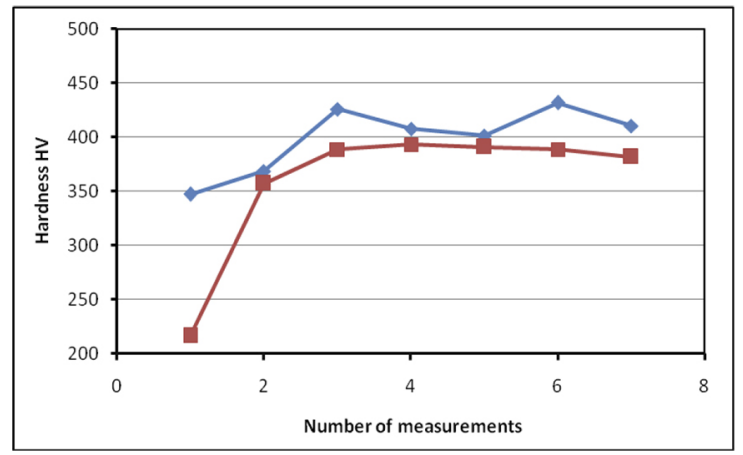

- Nitrogen

$\square$ Endothermic gas

Figure 4: Hardness values after the cross-sectioning of specimens annealed in a) nitrogen and b) endothermic gas.

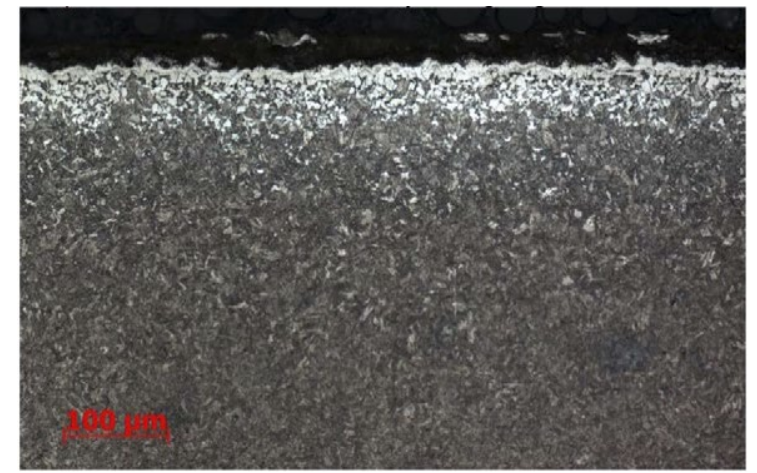

Figure 5: Microstructure of the specimen annealed in nitrogen.

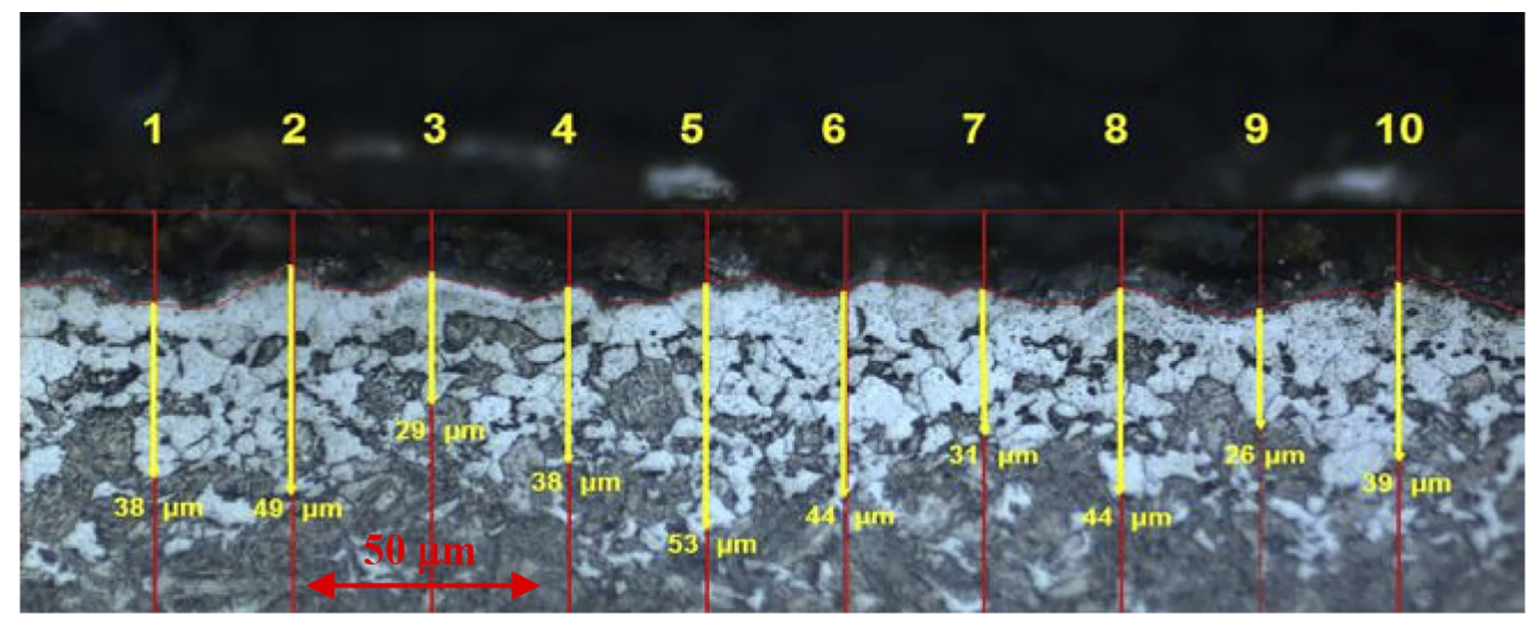

Figure 6: Measurements of the depth of decarburisation of sample annealed in nitrogen atmosphere. 


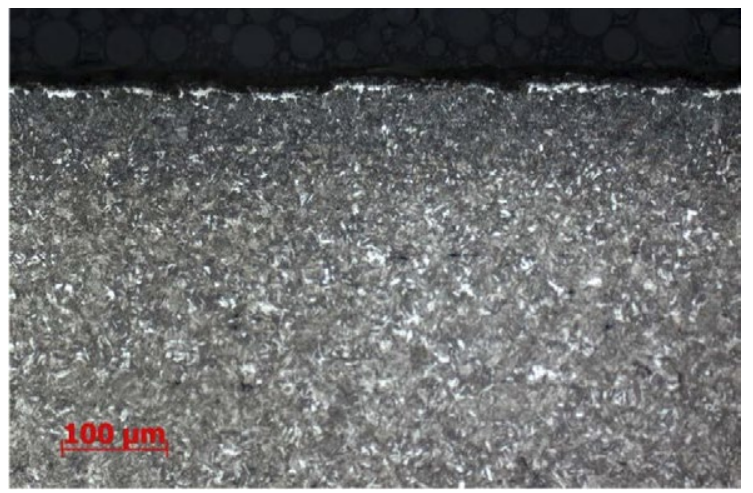

Figure 7: Microstructure of the specimen heated in endothermic gas.

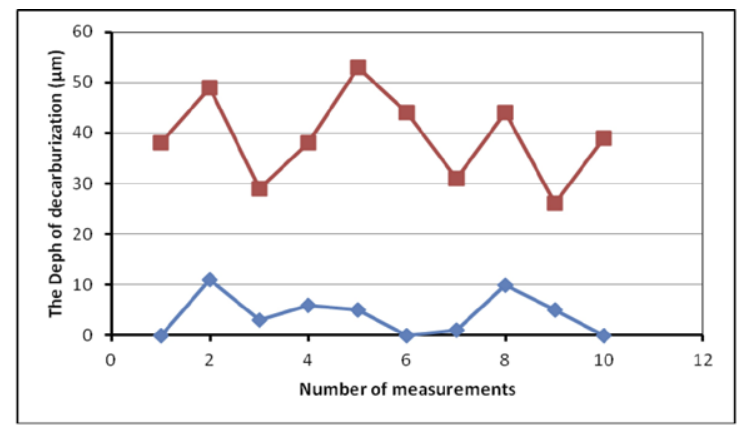

- Nitrogen

$\square$ Endothermic gas

Figure 9: The depth of the decarburised layer.

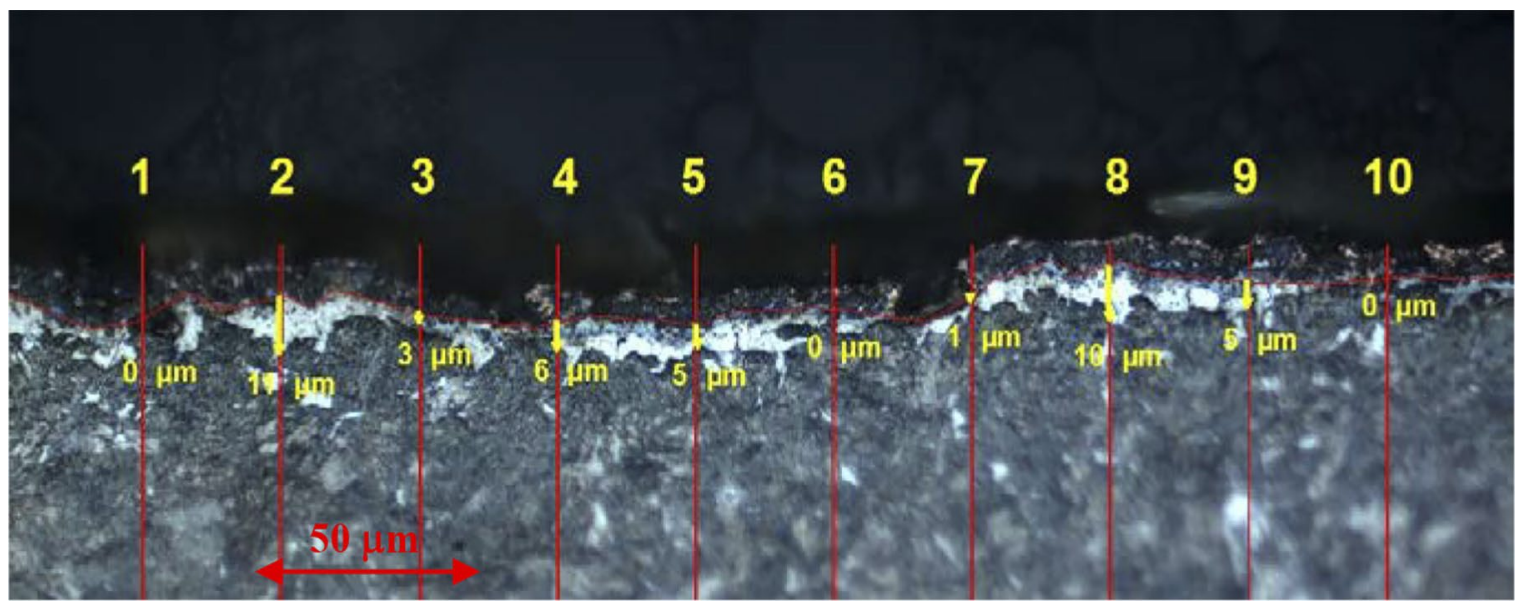

Figure 8: Measurements of the depth of decarburisation of sample annealed in endothermic gas.

The results of these measurements show that the values for hardness on the surface of the specimen heated in the atmosphere of nitrogen were much lower than the hardness values obtained in endothermic gas. At the same time, it is evident that hardness increases with the depth of the heat-treated steel. Figure 3a shows the measurement points of hardness in specimens annealed in a protective atmosphere of nitrogen, and Figure $3 \mathrm{~b}$ shows those in specimens annealed in a protective atmosphere of endothermic gas. Because of the different depths of the decarburised layers, the points of measurements are different.

Figure 4 shows the graph of the hardness values measured from the surface to the centre of the bolt. The figure makes it evident that the hardness of the bolt was the lowest on the surface (measurement 1 ) and increased as the measurement point went deeper. The measured hardness values were lower in the case of samples treated in nitrogen atmosphere.
Figure 5 shows the microstructure of the specimen heated in nitrogen atmosphere, and Figure 6 shows the depth measurements of the decarburised layer of bolt heated in a protective atmosphere of nitrogen. The maximum depth of decarbutisation was $53 \mathrm{~mm}$. In the decarburised layer, light grains of ferrite were found. Figure 7 shows the microstructure of the specimen heated in endothermic gas, while Figure 8 shows the depth of the decarburised layer of bolt heated in the protective atmosphere of endothermic gas. The maximum measured depth of decarburisation was $11 \mathrm{~mm}$. There was a light, thin layer of ferrite visible on the surface. Based on the measurements of the ferritic layer's depth, we drew a diagram (Figure 9), from which it is visible how deep from the surface the ferrite runs, which is a sign of decarburisation. Thus, the depth of the decarburisation layer is larger when heating the bolt in a protective atmosphere of nitrogen than when heating in endothermic gas. 


\section{Conclusion}

In this research, we studied the decarburisation of the surface of the bolt heated in a protective atmosphere and that then undergoes hardening and tempering. The goal of this work was to determine which gases help in achieving a smaller decarburised layer.

We carried out the research using two gases that are frequently used in the production process, namely, nitrogen and endothermic gas. We measured the hardness of the test specimens and arrived at the microstructure. Hardness measurements of the specimens made for metallographic examination make it evident that the hardness of the surface when heated in the atmosphere of nitrogen is smaller than that in the case of heating in endothermic gas.

How deep the decarburised layer goes was determined by metallographic testing. During the testing, we came to the conclusion that decarburisation is more intense and runs deeper on specimens that were heat-treated in the protective atmosphere of nitrogen than in those treated in the protective atmosphere of endothermic gas. Thus, specimens annealed in nitrogen atmosphere had a decarburised layer with the depth of $70 \mathrm{~mm}$, with the microstructure of ferrite prevailing at the beginning and later, a mixed microstructure of ferrite and martensite. In specimens that were heat-treated in endothermic gas, decarburisation on the surface was minimal and only reached a depth of $10 \mathrm{~mm}$.

Based on the results obtained, we can conclude that the protective atmosphere of endothermic gas offers better protection against decarburisation of the bolt than the protective atmosphere of nitrogen. The most suitable evaluation of the decarburised layer is through determination of a metallographic profile.

\section{References}

[1] Nitrogen-propane protective atmospheres for annealing and hardening operations in continuous furnaces [online]. Air Products and Chemicals, Inc., 2015. 1-9. [cited 30.2.2016]. Available on: <http://www.airproducts.com/ /media/downloads/article/N/ennitrogen-propane-protective-atmospheres.pdf $>$.
[2] Linde Gas. Furnace Atmospheres No. 2. Neutral Hardening and Annealing [online]. Special Edition. [cited 30.2.2016]. Available on: <http://www.techgaz.ru/ userFiles/file/FA.2\%20Hardening\%20and $\% 20$ Annealing.pdf $>$.

[3] Herring, H.D. (2010): Annealing of Wire Products: Atmospheres [online]. Winter 2010/Wire Forming Technology International. [cited 30.5.2017]. Available on: <http://www.heat-treat-doctor.com/documents/ annealing\%20of\%20wire\%20products.pdf $>$.

[4] Buss, D.: Optimierte Wärmebehandlung in der tahlverarbeitung. Messer Group GmbH. [online]. [cited 30.5.2017]. Available on: <http://old.messergroup. com/de/Info_Download/Fachbroschueren/Metallurgie/Haerten-mit-Stickstoff.pdf $>$.

[5] Herring, H.D. (2009): Considerations in Heat Treatment Part One: Furnace Atmospheres. [online]. IndustrialHeating.com- october 2009. str. 45-48. [cited 30.5.2017]. Available on: http://www.heat-treat-doctor.com/documents/Considerations\%20in\%20HT1. pdf $>$.

[6] Rodič, A. Določevanje globine razogljičenja pri različnih vrstah jekel [online]. Železarna Ravne. pp. 105-115. [cited 30. 5. 2017]. Available on: <file:///C:/ Documents\%20and\%20Settings/Uporabnik/My\%20 Documents/Downloads/Doloevanje_URN-NBN-SIDOC-P7AWMU45.pdf>.

[7] Grešovnik, F., Grešovnik, M.M. (2002): Vpliv segrevanja in razogljičenja hadfieldovega jekla na spreminjanje fazne sestave. Materiali in tehnologije 36, 3/4, pp. 143-146.

[8] Torkar, M. (2004). Varovalni premaz za zmanjšanje škajanja in razogljičenja površine jekla med ogrevanjem pred vročo predelavo. Patent št. 21562: št. prijave P-200400257.

[9] Standard ISO 9001:2015. Sistem vodenja kakovosti $\mathrm{v}$ avtomobilski industriji [online]. [cited 30. 5. 2017]. Available on: < http://www.siq.si/ocenjevanje_sistemov_vodenja/storitve/sistemi_vodenja_kakovosti_v_ avtomobilski_industriji/index.html>.

[10] Knez, F. (2017): Distančni vijak. Tehnološki list toplotne obdelave. Kovikor, d. o. o., Šmartno pri Litiji.

[11] Leban, M.B. (2015): Poročilo o analizi toplotno obdelanih vijakov, št. P0339/15-440-1. Zavod za gradbeništvo Ljubljana. Ljubljana. 